\begin{tabular}{|c|c|}
\hline \multirow{3}{*}{ 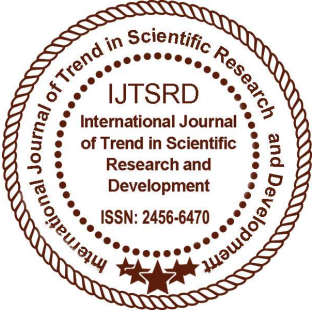 } & $\begin{array}{l}\text { International Journal of Trend in Scientific } \\
\text { Research and Development (IJTSRD) }\end{array}$ \\
\hline & International Open Access Journal \\
\hline & ISSN No: 2456 - 6470 | www.ijtsrd.com | Volume - 2 | Issue - 4 \\
\hline
\end{tabular}

\title{
Performance and Emission Characteristics of Biodiesel From Algae in A Diesel Engine
}

\author{
J Mahendran \\ Assistant Professor \\ Mother Terasa College of Engineering and Technology, Pudukkottai, Tamil Nadu, India
}

\begin{abstract}
Rapid industrialization and growth in population has resulted in the rapid increase in energy demand. Indiscriminate use of fossil fuels has led to extinction of petroleum sources. Pollutant emissions from diesel engines has caused major impacts in disturbing the ecological system. To overcome these problems, focus is towards alternative sources. Biodiesel, derived from vegetable oils, animal fats and algae is the future prospect. The paper reviews the research on impact of biodiesel on performance. Fuel properties like calorific value, flash point and cetane value of biodiesel and biodiesel blends(B5,B15,B25) were found comparable petroleum diesel. Performance results reveal that most of the biodiesel, give higher brake thermal efficiency and lower brake -specific fuel consumption
\end{abstract}

Keywords: Diesel engine, Diesel-biodiesel-bioethanol emulsion fuels, emulsion characteristics, Engine performanc, and Exhaust emission

\section{INTRODUCTION}

Rapid industrialization and growth in population has resulted in the rapid increase in energy demand. Indiscriminate use of fossil fuels has led to extinction of petroleum sources. Pollutant emissions from diesel engines has caused major impacts in disturbing the ecological system. To overcome these problems, focus is towards alternative sources. Biodiesel, derived from vegetable oils, animal fats and algae is the future prospect. The scope of this work is to reveal microalgae as an alternative energy source for producing biodiesel. In a broad-spectrum shows that microalgae is a sustainable energy source for biodiesel. This present paper evaluates the combustion, performance, and emission characteristics of bio fuel and its blends with diesel.
The brake power, torque, specific fuel consumption, thermal efficiency and exhaust emissions are reviewed.

\section{PROBLEM IDENTIFICATION}

1. The unburnt fuel particle create high degree exhaust gas temperature which create harmful effect in ozone layer.

2. The transesterification procedure cannot be successful when the FFA (Free fatty acid) content is more than $3 \%$.

3. There is a drastic increase in smoke emission.

\section{METHODOLOGY}

The various research methodologies of our project is shown in the figure

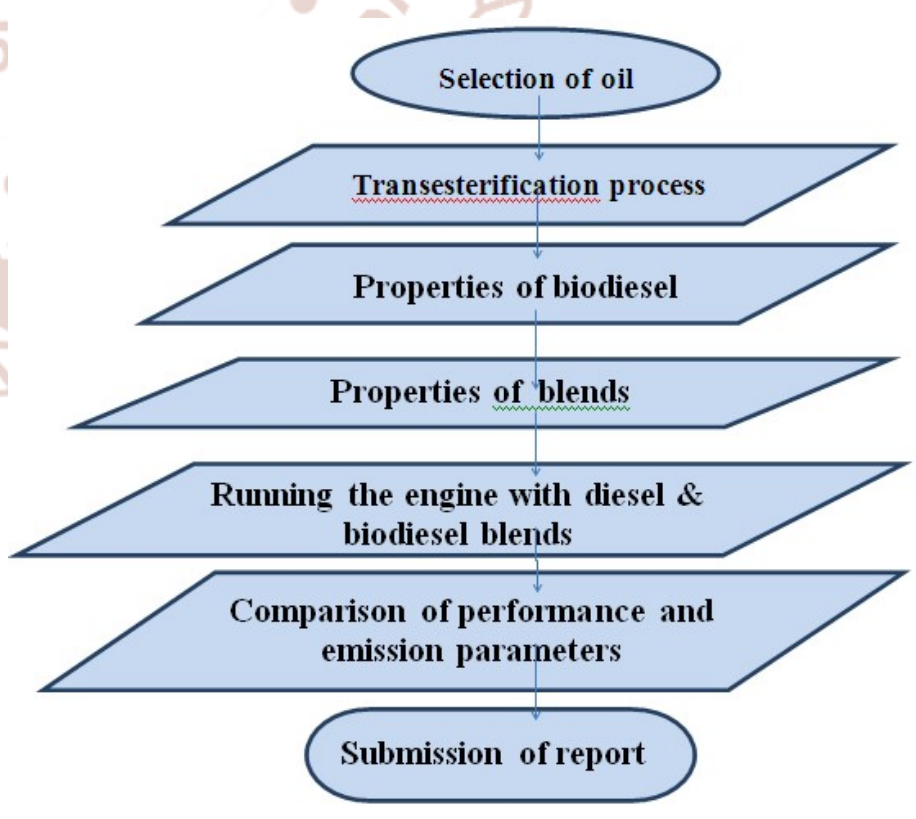

Flowchart Research Methodology 
International Journal of Trend in Scientific Research and Development (IJTSRD) ISSN: 2456-6470

PROPERTIES OF FUELS

Table 4.1 Properties Of Fuels

\begin{tabular}{|l|l|l|l|l|}
\hline S.NO & \multicolumn{1}{|c|}{ FUELS } & \multicolumn{1}{|c|}{$\begin{array}{c}\text { DENSITY }(\boldsymbol{p}) \\
\mathrm{kg} / \mathrm{m}^{3}\end{array}$} & $\begin{array}{c}\text { CALORIFIC } \\
\text { VALUE }(\mathrm{kJ} / \mathrm{kg})\end{array}$ & $\begin{array}{l}\text { KINMATIC } \\
\text { VISCOSITY in centistoke }\end{array}$ \\
\hline 1. & DIESEL & 860 & 43500 & 3.56 \\
\hline 2. & ALGAE OIL & 926 & 43120 & 3.4 \\
\hline 3. & B5 & 870 & 42150 & 4.12 \\
\hline 4. & B15 & 889 & 41837 & 5.5 \\
\hline 5. & B25 & 895 & 41432 & 6.61 \\
\hline
\end{tabular}

Table 4.2 Flash And Fire Point

\begin{tabular}{|l|l|l|l|}
\hline \multicolumn{1}{|c|}{ S.NO } & \multicolumn{1}{|c|}{ FUEL BLENDS } & \multicolumn{1}{|c|}{ FLASH POINT ${ }^{\circ} \mathrm{C}$} & \multicolumn{1}{|c|}{ FIRE POINT ${ }^{\circ} \mathrm{C}$} \\
\hline 1. & DIESEL & $62^{\circ} \mathrm{C}$ & $65^{\circ} \mathrm{C}$ \\
\hline 2. & ALGAE OIL & $74^{\circ} \mathrm{C}$ & $76^{\circ} \mathrm{C}$ \\
\hline 3. & B5 & $58^{\circ} \mathrm{C}$ & $60^{\circ} \mathrm{C}$ \\
\hline 4. & B15 & $68^{\circ} \mathrm{C}$ & $70^{\circ} \mathrm{C}$ \\
\hline 5. & B25 & $76^{\circ} \mathrm{C}$ & $78^{\circ} \mathrm{C}$ \\
\hline
\end{tabular}

Table 5.1 specifications of the engine

\begin{tabular}{|l|l|}
\hline \multicolumn{1}{|c|}{ Specification of the test engine type } & Vertical, water cooled, four stroke \\
\hline Number of cylinder & One \\
\hline Bore & $87.5 \mathrm{~mm}$ \\
\hline Stroke & $110 \mathrm{~mm}$ \\
\hline Compression ratio & $16.7: 1$ \\
\hline Maximum power & $3.7 \mathrm{~kW}$ \\
\hline Speed & $1500 \mathrm{rpm}$ \\
\hline Dynamometer & Eddy current dynamometer \\
\hline Injection timing & $23^{\circ} \mathrm{before} \mathrm{TDC}$ \\
\hline Injector opening pressure & $200 \mathrm{~kg} / \mathrm{cm}^{2}$ \\
\hline
\end{tabular}

\section{PERFORMANCE CHARACTERISTICS FOR DIESEL}

Table 6.1 Performance Characteristics Of Diesel

\begin{tabular}{|l|l|l|l|l|l|l|l|}
\hline S.No & $\begin{array}{c}\text { Load } \\
(\mathrm{kg})\end{array}$ & $\begin{array}{c}\text { Time taken } \\
\text { for 10cc of } \\
\text { fuel (sec) }\end{array}$ & $\begin{array}{c}\text { BP } \\
(\mathrm{kW})\end{array}$ & $\begin{array}{c}\text { BMIEP } \\
(\mathrm{bar})\end{array}$ & $\begin{array}{c}\text { TFC } \\
(\mathrm{kg} / \mathrm{h})\end{array}$ & $\begin{array}{c}\text { SFC } \\
(\mathrm{kg} / \mathrm{kW}-\mathrm{h})\end{array}$ & $\eta_{\text {Bte (\%) }}$ \\
\hline 1. & 0 & 93.42 & 0 & 0 & 0.327 & 0 & 0 \\
\hline 2. & 2 & 74.91 & 2 & 1.13 & 0.408 & 0.480 & 14 \\
\hline 3. & 4 & 58.5 & 4 & 2.295 & 0.523 & 0.379 & 22 \\
\hline 4. & 6 & 50.6 & 6 & 3.34 & 0.604 & 0.292 & 29 \\
\hline
\end{tabular}

Table 6.2 Performance Characteristics Of B5

\begin{tabular}{|c|c|c|c|c|c|c|c|}
\hline S.No & $\begin{array}{c}\text { Load } \\
\text { (kg) }\end{array}$ & $\begin{array}{l}\text { Time taken } \\
\text { for } 10 \mathrm{cc} \text { of } \\
\text { fuel (sec) }\end{array}$ & $\begin{array}{c}\mathrm{BP} \\
(\mathrm{kW})\end{array}$ & $\begin{array}{c}\text { FP } \\
(\mathrm{kW})\end{array}$ & $\begin{array}{c}\text { TFC } \\
(\mathrm{kg} / \mathrm{h})\end{array}$ & $\begin{array}{c}\text { SFC (kg/kW- } \\
\text { h) }\end{array}$ & $\eta_{\text {Bte }}(\%)$ \\
\hline 1. & 0 & 67.5 & 0 & 2 & 0.457 & 0 & 0 \\
\hline 2. & 2 & 58.5 & 2 & 2 & 0.529 & 0.2645 & 32.23 \\
\hline 3. & 4 & 54.5 & 4 & 2 & 0.568 & 0.142 & 60.14 \\
\hline 4. & 6 & 46.5 & 6 & 2 & 0.665 & 0.110 & 77.06 \\
\hline
\end{tabular}


International Journal of Trend in Scientific Research and Development (IJTSRD) ISSN: 2456-6470

The table 6.3 shows that performance characteristics of B15 fuel. The fuel B15 contain 15\% of bio-fuel and $85 \%$ of diesel. The B15 is give the higher thermal efficiency compare with other bio-diesel. But less thermal efficiency to the diesel.

Table 6.3 Performance Characteristics Of B15

\begin{tabular}{|l|l|l|l|l|l|l|l|}
\hline S.No & $\begin{array}{c}\text { Load } \\
(\mathrm{kg})\end{array}$ & $\begin{array}{c}\text { Time taken } \\
\text { for 10cc of } \\
\text { fuel (sec) }\end{array}$ & $\begin{array}{c}\text { BP } \\
(\mathrm{kW})\end{array}$ & $\begin{array}{c}\text { FP } \\
(\mathrm{kW})\end{array}$ & $\begin{array}{c}\text { TFC } \\
(\mathrm{kg} / \mathrm{h})\end{array}$ & $\begin{array}{l}\text { BSFC (kg/kW- } \\
\text { h) }\end{array}$ & \multicolumn{1}{|}{$\eta_{\text {Bte (\%) }}$} \\
\hline 1. & 0 & 68.5 & 0 & 1.8 & 0.452 & 0 & 0 \\
\hline 2. & 2 & 58 & 2 & 1.8 & 0.533 & 0.267 & 32.31 \\
\hline 3. & 4 & 53 & 4 & 1.8 & 0.584 & 0.146 & 61.9 \\
\hline 4. & 6 & 47 & 6 & 1.8 & 0.6587 & 0.109 & 78.38 \\
\hline
\end{tabular}

Table 6.4 Performance Characteristics Of B25

\begin{tabular}{|l|l|l|l|l|l|l|l|}
\hline S.No & $\begin{array}{c}\text { Load } \\
(\mathrm{kg})\end{array}$ & $\begin{array}{c}\text { Time taken } \\
\text { for 10ce of } \\
\text { fuel }(\mathrm{sec})\end{array}$ & $\begin{array}{c}\text { BP } \\
(\mathrm{kW})\end{array}$ & $\begin{array}{c}\text { FP } \\
(\mathrm{kW})\end{array}$ & $\begin{array}{c}\text { TFC } \\
(\mathrm{kg} / \mathrm{h})\end{array}$ & $\begin{array}{c}\text { BSFC (kg/kW- } \\
\text { h) }\end{array}$ & \multicolumn{1}{|}{$\eta_{\text {Bte (\%) }}$} \\
\hline 1. & 0 & 76 & 0 & 1.6 & 0.407 & 0 & 0 \\
\hline 2. & 2 & 62.5 & 2 & 1.6 & 0.487 & 0.256 & 33.2 \\
\hline 3. & 4 & 55.5 & 4 & 1.6 & 0.557 & 0.134 & 62.63 \\
\hline 4. & 6 & 48.5 & 6 & 1.6 & 0.638 & 0.11 & 79.96 \\
\hline
\end{tabular}

The table 6.4 shows that performance characteristics of B25 fuel. The fuel B25 contain 25\% of bio-fuel and $75 \%$ of diesel. The B25 is give the higher thermal efficiency compare with other bio-diesel. But less thermal efficiency to the diesel.

6.1.5 BRAKE THERMAL EFFICIENCY (BTE)

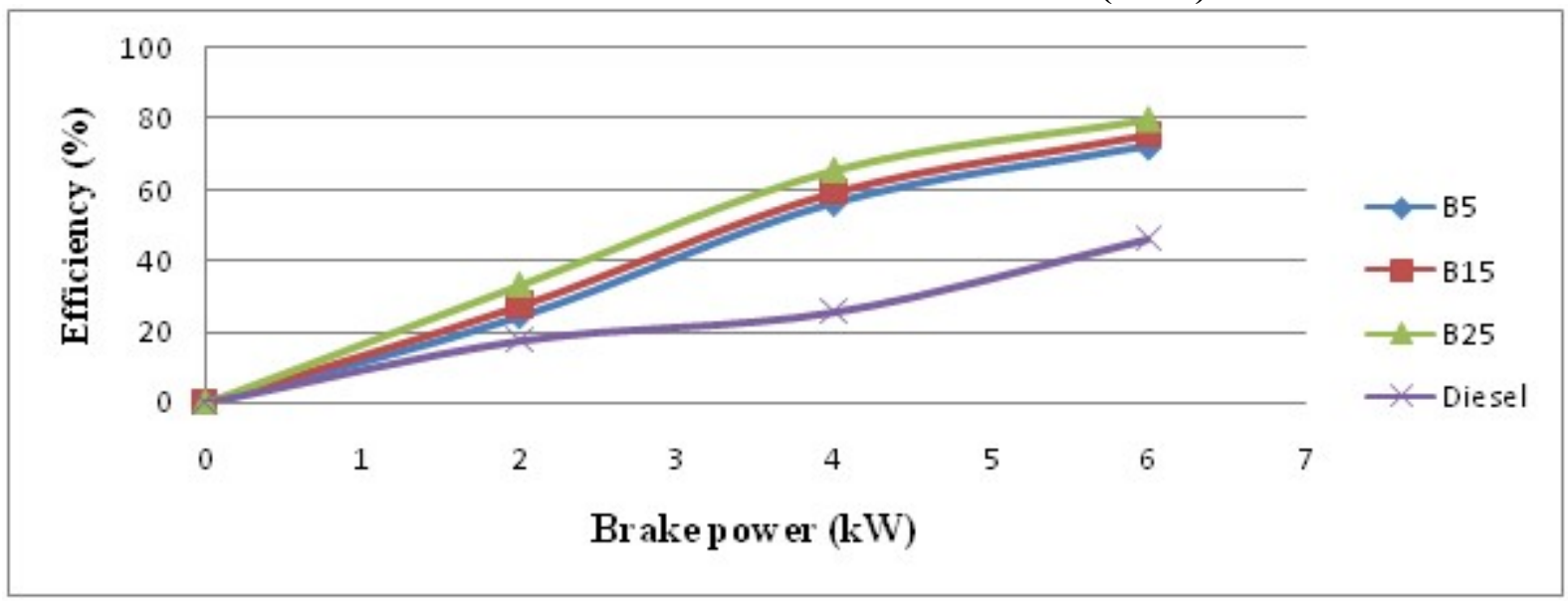

Figure 6.1 Comparison Of Brake Thermal Efficiency

The figure 6.1 is show the thermal efficiency of fuels. Brake power is taken in $\mathrm{x}$-axis and thermal efficiency should be taken in y-axis. the thermal efficiency of the blends has been compared with diesel fuel at various loads and it is shown in figure 6.1. It is observed that the thermal efficiency for B25 is higher than all blends and also with diesel.

\section{SPECIFIC FUEL CONSUMPTION}

In the graph, brake power is taken in x-axis and is taken Specific Fuel Consumption(SFC) in y-axis. The SFC of the blends ha sbeen compared with diesel fuel at varios loads and it is shown in figure 6.2. it is observed that the SFC is same as the bio-fuels for the entire range of load. 
International Journal of Trend in Scientific Research and Development (IJTSRD) ISSN: 2456-6470

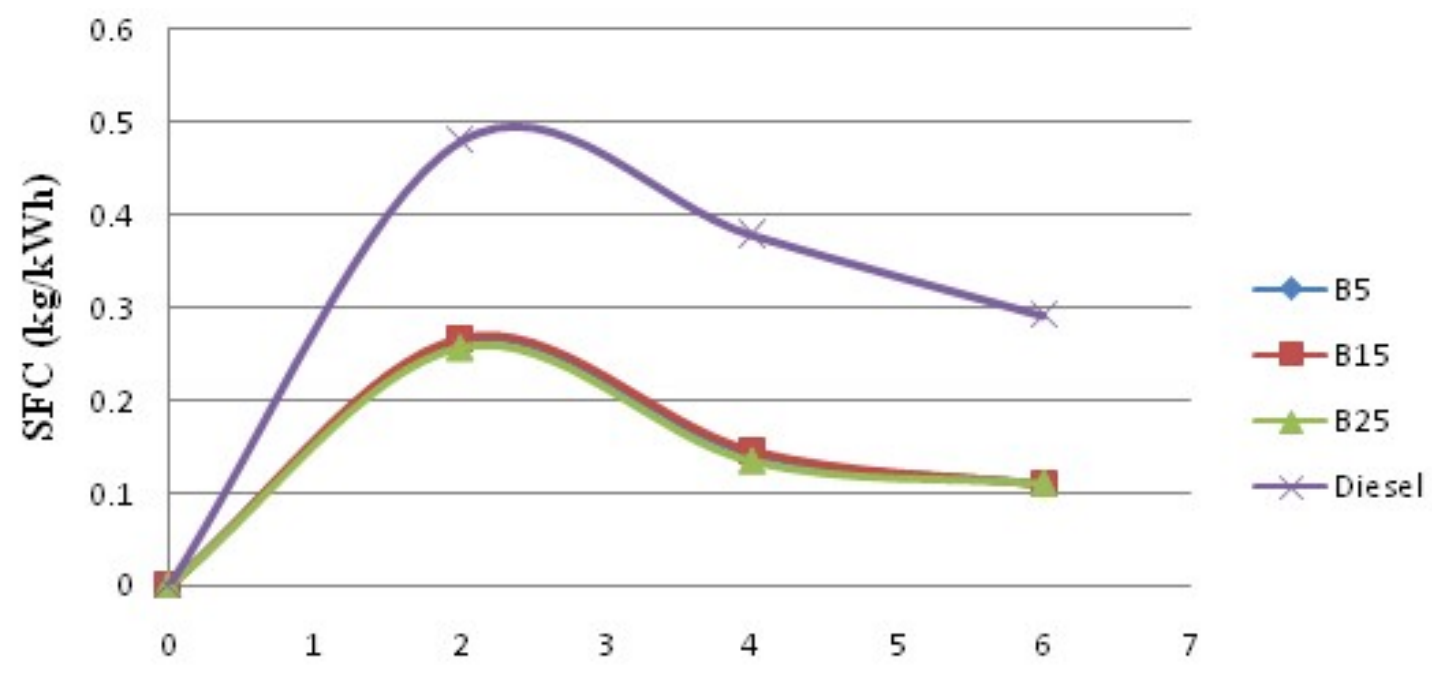

Brake pow er (kw)

Figure 6.2 Comparison Of SFC

\begin{tabular}{|l|l|l|l|l|l|l|l|l|l|}
\hline $\begin{array}{c}\text { S. } \\
\text { no }\end{array}$ & $\begin{array}{c}\text { Load } \\
(\text { amps })\end{array}$ & $\begin{array}{c}\text { Voltage } \\
(\mathbf{V})\end{array}$ & $\begin{array}{c}\text { Speed( } \\
\text { rpm })\end{array}$ & $\begin{array}{c}\text { Time } \\
(\mathrm{sec})\end{array}$ & $\begin{array}{c}\mathrm{CO} \\
(\%)\end{array}$ & $\begin{array}{c}\mathrm{HC} \\
(\mathrm{ppm})\end{array}$ & $\begin{array}{c}\mathrm{CO}_{2} \\
(\%)\end{array}$ & $\begin{array}{c}\mathrm{O}_{2} \\
(\%)\end{array}$ & $\begin{array}{c}\mathrm{NO}_{\mathrm{X}} \\
(\mathrm{ppm})\end{array}$ \\
\hline 1 & 0 & 230 & 1500 & 55 & 0.03 & 11 & 0.80 & 19.93 & 12 \\
\hline 2 & 2 & 230 & 1500 & 54 & 0.03 & 10 & 0.70 & 19.84 & 20 \\
\hline 3 & 4 & 230 & 1500 & 49.5 & 0.02 & 9 & 0.90 & 19.70 & 24 \\
\hline 4 & 6 & 230 & 1500 & 47.5 & 0.02 & 10 & 1.10 & 19.36 & 32 \\
\hline
\end{tabular}

Table 6.5 Emission Characteristics Of Diesel

EMISSION CHARACTERISTICS OF DIESEL

Table 6.6 Emission Characteristics Of B5

\begin{tabular}{|l|l|l|l|l|l|l|l|l|l|}
\hline S.no & $\begin{array}{c}\text { Load } \\
(\mathrm{Amps})\end{array}$ & $\begin{array}{c}\text { Voltage } \\
(\mathrm{V})\end{array}$ & $\begin{array}{c}\text { Speed } \\
(\mathrm{rpm})\end{array}$ & $\begin{array}{c}\text { Time } \\
(\mathrm{sec})\end{array}$ & $\begin{array}{c}\mathrm{CO} \\
(\%)\end{array}$ & $\begin{array}{c}\mathrm{HC} \\
(\mathrm{ppm})\end{array}$ & $\begin{array}{c}\mathrm{CO}_{2} \\
(\%)\end{array}$ & $\begin{array}{c}\mathrm{O}_{2} \\
(\%)\end{array}$ & $\begin{array}{c}\mathrm{NO}_{\mathrm{X}} \\
(\mathrm{ppm})\end{array}$ \\
\hline 1 & 0 & 230 & 1500 & 67.5 & 0.01 & 6 & 0.10 & 20.74 & 3 \\
\hline 2 & 2 & 230 & 1500 & 58.5 & 0.01 & 1 & 0.30 & 20.55 & 8 \\
\hline 4 & 4 & 230 & 1500 & 54.5 & 0.03 & 8 & 1.30 & 19.42 & 19 \\
\hline
\end{tabular}

Table 6.7 Emission Characteristics Of B15

\begin{tabular}{|l|l|l|l|l|l|l|l|l|l|}
\hline S.no & $\begin{array}{c}\text { Load } \\
(\mathrm{Amps})\end{array}$ & $\begin{array}{c}\text { Voltage } \\
(\mathrm{V})\end{array}$ & $\begin{array}{c}\text { Speed } \\
(\mathrm{rpm})\end{array}$ & $\begin{array}{c}\text { Time } \\
(\mathrm{sec})\end{array}$ & $\begin{array}{c}\mathrm{CO} \\
(\%)\end{array}$ & $\begin{array}{c}\mathrm{HC} \\
(\mathrm{ppm})\end{array}$ & $\begin{array}{c}\mathrm{CO}_{2} \\
(\%)\end{array}$ & $\begin{array}{c}\mathbf{O}_{2} \\
(\%)\end{array}$ & $\begin{array}{c}\mathbf{N O}_{\mathbf{X}} \\
(\mathbf{p p m})\end{array}$ \\
\hline 1 & 0 & 230 & 1500 & 68.5 & 0.04 & 20 & 0.90 & 19.63 & 15 \\
\hline 2 & 2 & 230 & 1500 & 58 & 0.02 & 16 & $1 . .10$ & 19.15 & 34 \\
\hline 3 & 4 & 230 & 1500 & 53 & 0.02 & 10 & 1.30 & 19.06 & 40 \\
\hline 4 & 6 & 230 & 1500 & 47 & 0.02 & 9 & 1.50 & 18.72 & 60 \\
\hline
\end{tabular}

Table 6.8 Emission Characteristics Of B25

\begin{tabular}{|l|l|l|l|l|l|l|l|l|l|}
\hline S.no & $\begin{array}{c}\text { Load } \\
(\mathrm{Amps})\end{array}$ & $\begin{array}{c}\text { Voltage } \\
(\mathrm{V})\end{array}$ & $\begin{array}{c}\text { Speed } \\
(\mathrm{rpm})\end{array}$ & $\begin{array}{c}\text { Time } \\
(\mathrm{sec})\end{array}$ & $\begin{array}{c}\mathrm{CO} \\
(\%)\end{array}$ & $\begin{array}{c}\mathrm{HC} \\
(\mathrm{ppm})\end{array}$ & $\begin{array}{c}\mathrm{CO}_{2} \\
(\%)\end{array}$ & $\begin{array}{c}\mathbf{O}_{2} \\
(\%)\end{array}$ & $\begin{array}{c}\mathbf{N O}_{\mathbf{X}} \\
(\mathrm{ppm})\end{array}$ \\
\hline 1 & 0 & 230 & 1500 & 76 & 0.03 & 10 & 0.70 & 20 & 14 \\
\hline 2 & 2 & 230 & 1500 & 63.5 & 0.03 & 10 & 1 & 19.50 & 28 \\
\hline 3 & 4 & 230 & 1500 & 55.5 & 0.02 & 7 & 1 & 19.50 & 37 \\
\hline 4 & 6 & 230 & 1500 & 48.5 & 0.03 & 11 & 1.40 & 18.93 & 59 \\
\hline
\end{tabular}




\section{Brake Power vs $\mathrm{CO}_{2}$}

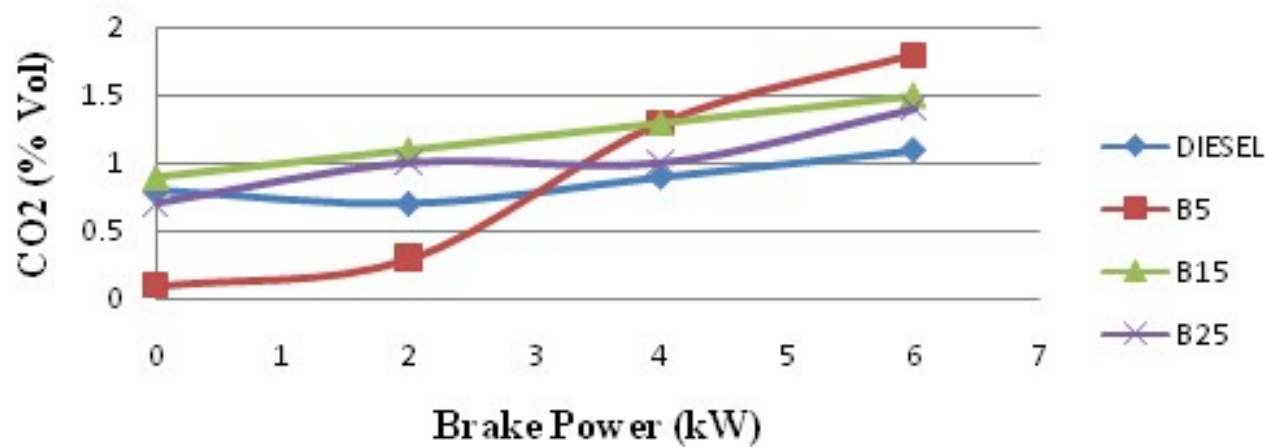

Figure 6.4 Comparison Of $\mathrm{Co}_{2}$

This is mainly due to improper combustion of fuel efficiency. $\mathrm{CO}_{2}$ Emission is increase in the blends in the blends of $\mathrm{B} 5$ and $\mathrm{B} 15$. The $\mathrm{CO}_{2}$ emission of $\mathrm{B} 25$ nearer to diesel.

\section{UNBURNED HYDROCARBONS}

The unburned hydrocarbon emission of blends of Algae oil is more compared to that for neat diesel for all loads. This is because of poor mixture formation tendency of blends of Algae oil as shown in figure 6.5.

\section{Brake Power vs HC}

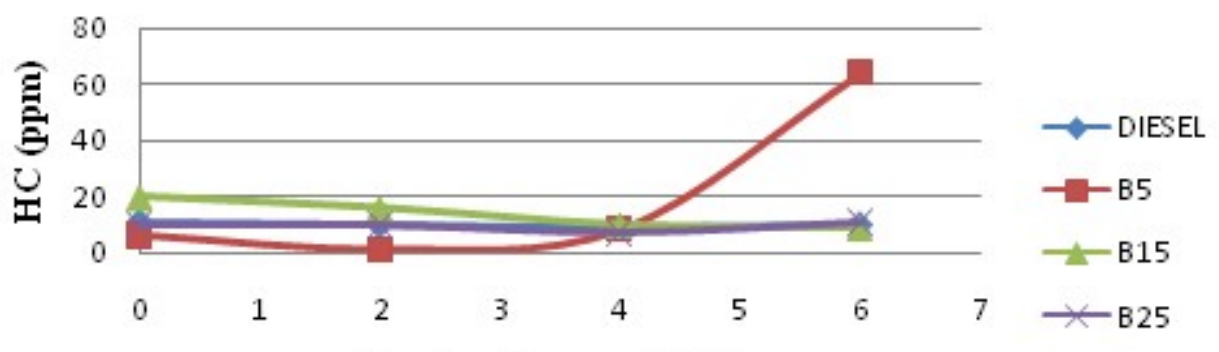

Brake Power (kW)

Figure 6.5 comparison of $\mathrm{HC}$

In addition to the other factors, the lower thermal efficiency wth these blends also is responsible for this trend. It may be noted that a lower thermal efficiency with these blends will lead to injection of higher quantities for the same load condition.

\section{OXIDES OF NITROGEN}

Figure 6.6 indicates that blends of Algae oil shows lower $\mathrm{NO}_{\mathrm{x}}$ emission compared to neat diesel fuel. This is due to atomization of algae oil leads to poor combustion and lead lower $\mathrm{NO}_{\mathrm{x}}$ emission. Compare all the blend $\mathrm{B} 25$ is emitted lower $\mathrm{NO}_{\mathrm{x}}$ emission.

\section{Brake Power vs NOx}

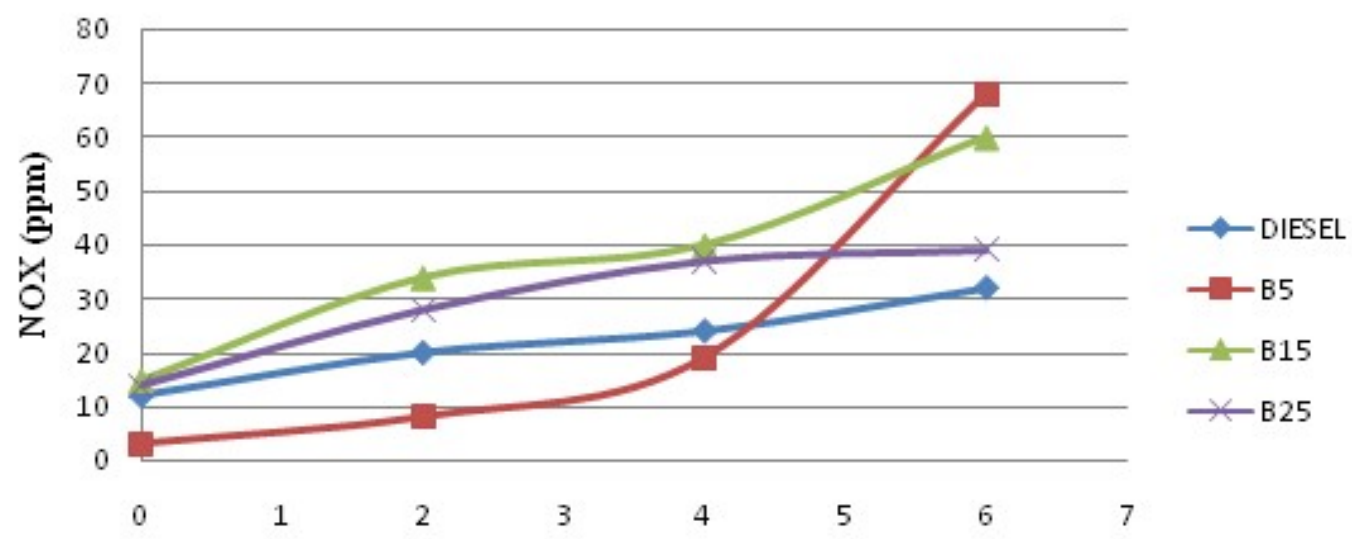

Brake Pow er (kW)

Figure 6.6 Comparison Of $\mathrm{No}_{\mathrm{x}}$ 


\section{CONCLUSION}

When compared to all the blends of the bio-diesel has high efficiency and in the mean while the specific fuel consumption was to be lower than the various blends with the diesel. The carbon monoxide emission is higher than that of diesel blends. This is due to higher viscosity and poor atomization tendency of algae oil leads to poor combustion and higher carbon monoxide emission. The unburned hydrocarbon emission of blends of algae oil is more compared to that for neat diesel for all loads. This is because of poor mixture formation tendency of blends of algae oi. When compared to the neat diesel blend B25 is emitted $41 \%$ lower NOx emission. The specific fuel consumption is increased in the case of Algae Oil-Diesel blends compared to neat diesel. The unburned hydrocarbon and carbon monooxide emissions are increased with blends of Algae oil-Diesel as compared to neat diesel. The smoke density also increase for the blends of Algae oil-diesel compared to neat diesel. The oxides of nitrogen (NOx) diesel. The exhaust gas temperature decrease with the bleds Algae oil compared to neat diesel. In general the performance and emission level of algae diesel blends does not improve, but it can be used as a low cost alternative fuel for diesel engine.

\section{FUTURE WORK}

The future scope is about to be a certain amount of ethanol will be added to the existing one to increase the properties of bio diesel nearer to the neat be $\mathrm{CO}$ and $\mathrm{CO} 2$. Hence th eengine performance is also been increased. Emission test shows reduction in NOx and smoke in exhaust gases for Algae oil with respect to conventional fuels at medium and higher power output.

\section{REFERNCES}

1. Ahmad, Demirbas.A(2007),“ Importance Of Biodiesel As Transportation Fuel”. Energy Policy, 35, 4661-70.

2. Avinash Kumar Agarwal, Chen.H, Geng.L.M, Bian.Y(2010), "Experimental Studies On The
Combustion Characteristics And Performance Of A Direct Injection Engine Fuelled With Biodiesel Blends". Energy Conversion And Management, 51, 2985-2992.

3. Balachanda.R.K, Costa, Lima.J.R, Ggrilo, Bezerrafilho.B (2008),"Exhaust Emissions Characteristics: An Experimental Study On Diesel Engine Operated With Mixtures Of Diesel And Natural Gas". Brazilian journal of petroleum and gas. V. 2, n. 1, p. 36-44.

4. Banapurmatha N.R,Bradley D. Wahlen, Robert M. Willis, Lance C.(2011),"Biodiesel production by simultaneous extraction and conversion of total lipids from microalgae, cyanobacteria, and wild mixed-cultures" Volume 102, Issue 3, Pages 2724-2730.

5. Colla,Tariq, Saqib Ali, Fiaz Ahmad, Mushtaq Ahmad (2011),"Identification, FT-IR, NMR $\left({ }^{1} \mathrm{H}\right.$ and ${ }^{13} \mathrm{C}$ ) and $\mathrm{GC} / \mathrm{MS}$ studies of fatty acid methyl esters in biodiesel from rocket seed oil"Volume 92, Issue 3, Pages 336-341.

6. Costa, Agarwal A K(2007),“Biofuels (alcohols and biodiesel) applications as fuels for internal combustion engines", Progress in Energy and Combustion Science, no. 3, 233-271, DOI 10.1016/j.pecs.2006.08.003.

7. Demirbas, Grau B, Bernat E, Antoni R, JordiRoger R, Rita P (2011),"Small-scale production of straight vegetable oil from rapeseed and its use as biofuel in the Spanish territory".

8. Donghui, Qi,PoitratE(1999), “The potential of liquid biofuels In France. Renewable Energy; 16:1084-9.

9. Gami, Demirbas.A (2003),"Biodiesel fuels from vegetable oils via catalytic and non-catalytic supercritical alcohol transesterifications and other methods:a survey. Energy Conversion and Management;44:2093-109. 